\title{
Preparing for Military Action: Judith's Purificatory Washing in Judith 12:7
}

\author{
Joseph Scales | ORCID: 0000-0001-7288-8035 \\ Department of Theology and Religion, University of Birmingham, \\ Birmingham, UK \\ josephdscales@gmail.com
}

Published online: 26 April 2021

\begin{abstract}
In the twelfth chapter of the Book of Judith, the eponymous heroine departs from the Assyrian camp in order to bathe and pray over three successive nights. Judith's bath has been interpreted as a ritual bath which achieves purification. Scholars have offered various reasons for Judith's purificatory wash, but none fully account for all the details of this episode. This paper discusses the proposed solutions and offers a new suggestion to account for Judith's bath; Judith bathes to prepare herself for the assassination of Holofernes.
\end{abstract}

\section{Keywords}

Judith - purity - bathing - prayer - warfare

The Book of Judith presents a fictionalised narrative in which the Israelites are threatened by an Assyrian invasion. ${ }^{1}$ They are rescued from conquest by the actions of Judith, an exemplary woman. She enters the Assyrian encampment outside of her town, Bethulia, and impresses the general Holofernes by telling him that she has come to advise him on the right time to conquer Bethulia

1 Levine Gera, Judith, 44, dates the text to around 100 вCE after much discussion. Dombkowski Hopkins, "Judith," 385 , dates the book slightly later to the reign of Salome Alexandra (76-67 ВСЕ). 
and then Jerusalem. This, however, is a pretext so Judith can assassinate the general before the Israelites attack the Assyrians, successfully routing them. Judith is often compared to many other biblical figures whom she emulates. ${ }^{2}$ She is portrayed as a pious woman, who observes the law and puts herself in danger to save her people. Judith 12:7 provides an intriguing reference to ritual washing, although the text itself is ambiguous about the exact reason for Judith's bath, and various explanations have been offered. In his study of ritual bathing in ancient Judaism, Jonathan Lawrence raises the possibilities that this bath was for purification (generally), prayer, or preparation for Judith's meal. ${ }^{3}$ Further possibilities include purification from gentile contact or purification from menstruation. This multiplicity of possible readings shows the lack of consensus among scholars and that no explanation has accounted sufficiently for the details of this narrative. Therefore, I will propose a new explanation, that Judith bathed to achieve purification for military action.

The text of Jdt 12:5-9 is preserved in Greek. ${ }^{4}$ The following text is taken from Robert Hanhart's critical edition; 5 the English translation is the NRSV (with amendments in italics).

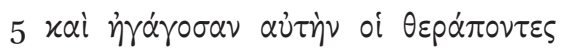

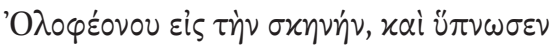

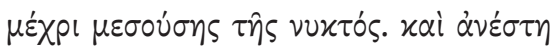

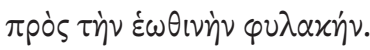

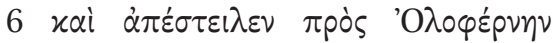

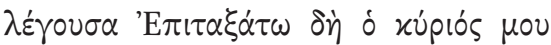

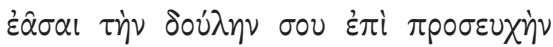
$\dot{\xi} \xi \varepsilon \lambda \theta \varepsilon i v$.
5 Then the servants of Holofernes brought her into the tent, and she slept until midnight. Towards the morning watch she got up.

6 She sent this message to Holofernes: "Let my lord now give orders to allow your servant to go out and pray."

2 On Judith's emulation of biblical figures, see Esler, Sex, 261, 274-285; Levine Gera, Judith, 48-52. Esler specifically compares Judith with David in 1 Sam 17 [LXX], Judith mirroring twenty elements from the Goliath narrative.

3 See Lawrence, Washing, 6o, also 109.

4 There is no known Hebrew text, although Wills, Judith, 2, notes that Jerome was maybe aware of an Aramaic version. Levine Gera is suspicious of Jerome's claim. The earliest sources which preserve the Greek text include Codices Vaticanus, Alexandrinus, and Sinaiticus. A 6th century CE Syriac version translates from the Greek. See Levine Gera, Judith, 14-17.

5 See Hanhart, Iudith, 122-123. 


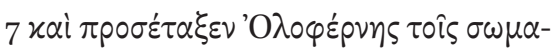

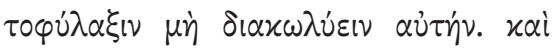

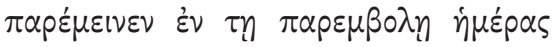

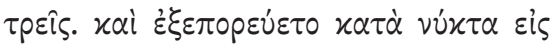

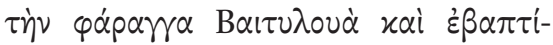

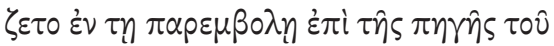

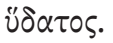

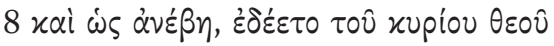

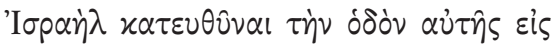

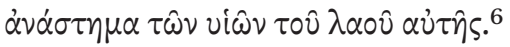

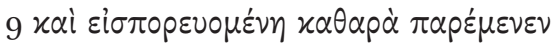

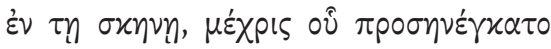

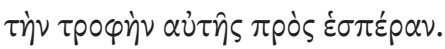

7 So Holofernes commanded his guards not to hinder her. She remained in the camp for three days. She went out each night to the valley of Bethulia and bathed in the spring of water in the camp.

8 After coming up, she prayed to the Lord God of Israel to direct her way for the triumph of her people.

9 Then she returned purified and stayed in the tent until she ate her food towards evening.

Some scholars have explained this pericope without directly referring to the concept that Judith's bathing was purificatory. These explanations explicitly or implicitly rely on understanding $\varkappa \alpha \theta \alpha \rho \dot{\alpha}$ in v. 9 as meaning "clean," or that Judith's purification was achieved by the prayer alone. Geoffrey Miller, for example, writes that Judith "is one of the most affluent citizens of Bethulia, but she pursues an ascetic lifestyle characterized by excessive fasting and the wearing of sackcloth." ${ }^{\prime 7}$ Other ascetics of the late Second Temple period were also noted for their bathing habits, such as the Essenes (War 2.128-131), the followers of Bannus (Life 11), and John the Baptist (Ant. 18.117; Mark 1:4-8). ${ }^{8}$ Like the Essenes (War 2.128), Judith (in Jdt 12:5-9) washes and prays before the sun rises. ${ }^{9}$ Therefore, Judith's washing could simply be indicative of her ascetic lifestyle. Another explanation is given by Amy-Jill Levine, who demonstrates a convincing comparison between Judith's and Achior's behaviour. Each

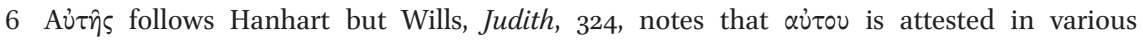
manuscripts.

7 Miller, "Femme Fatale," 241.

8 Steve Mason notes that Bannus' daily washing was more than simply ritual cleansing but could be understood as being linked to Roman bathing practices. Here "Josephus appears to be evoking a type of philosopher known well to his readers." See Mason, Life, 19-20 n. 84 . On the Essenes, see Mason, "Essenes," where Mason compares the presentation of the Essenes to the Roman image of Spartans.

9 This may be part of a repeated motif of Jdt 10:11-13:10a where the narrative is often set during the night. See Craven, Artistry, 96. 
character moves from their own people into another group and has the potential to be incorporated into their new community. As such, "Achior becomes a Jew first by sharing a meal with the leaders of Bethulia and secondly, primarily, through his circumcision. Judith too is physically altered (Jdt 10:7) in preparation for incorporation into the alien community, but her mark of difference is not permanent: the makeup is washed off each night."10 Thus Judith's washing forms part of her retention of Jewish identity and her bathing subverts her full integration with the Assyrians. A further explanation is that Judith leaves the camp to bathe and pray in order to establish a routine that facilitates her escape after she has slain Holofernes (Jdt 13:10)." This explanation does not address the fact that Judith bathes, which would be unnecessary if Judith was only planning her escape. A further dimension to consider is that two other key stories which feature women's bathing evoke a notion of sexuality. Both Bathsheba and Susanna's bathing narratives contain voyeuristic elements; tales about a woman bathing are tales about a man or men's viewing of this bathing. As Jennifer Glancy points out, in the Susanna narrative, "the reader is invited to consider Susanna and her beauty, to see what the elders see." Susanna's point of view is not presented, and the scene deliberately associates sexuality with a woman's private bath. ${ }^{12}$ This aspect could be part of a doublelayered reading of the narrative of the Book of Judith. In the first layer, these nightly visits certainly have a "literary function"13 to facilitate Judith's escape, and may also allude to the potential for the sexual encounter Holofernes was expecting. As with Bathsheba and Susanna, the bathing woman indicates this possibility to a male audience. However, on the second layer of the narrative, the audience is already aware that Judith is planning to kill (Jdt 9:9-13). ${ }^{14}$ Thus, the reader may intuit that this expectation is likely to be subverted. Judith's

$10 \quad$ Levine, "Sacrifice," 219.

11 See Hieke, "Torah," 102 n. 17; Levine Gera, Judith, 399; Moore, "Book of Judith," 64. Moore relies upon Craven, Artistry, 99 .

12 See Glancy, "Susanna 1," 158. See further Glancy, "Accused," 296-30o.

13 Holofernes comments on Judith's beauty frequently (Jdt 10:23; 11:21, 22) and expressly a desire to have sex with her ( Jdt 12:12, 16). A comparison could be made here with Jael, where the text alludes to her sexuality, allowing her to dispatch Sisera (Judg 4:17-22). See Ackerman, Warrior, 59-61; Klein, Deborah, 37-38. The audience here is also aware of the danger a woman presents to Sisera, as Deborah has told Barak in 4:9.

14 Sabine Van Den Eynde comments that Judith's nightly routine forms such dual function in the narrative. Judith's prayer is deceitful; she tells the Assyrians that the sin of the Israelites will be revealed (Jdt 11:17). The dual function assists her escape. See Van Den Eynde, "Crying," 223. See also Esler, Sex, 291, who makes much the same point. 
actual prayer relates to the second layer or "real plot,"15 i.e., that she accomplishes her goal. Thus, there are some practical reasons for Judith to establish a washing routine, and some reasons which may allude to narrative features of similar stories. However, the line that Judith returned to the camp "purified" suggests that the washing accomplished more than removing her make-up, providing an escape setup, or alluding to her sexuality.

\section{3} Judith's Washing as Related to Purification

Judith's washing should be understood as a ritual bath through which Judith purified. The connection between Judith's "purification" and her washing rests

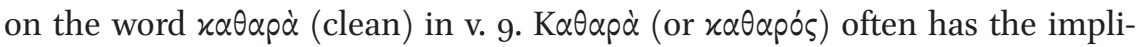
cation of ritual purity in the Septuagint (for instance, Lev 7:19; 13:6, 13, 17, 34, 37, 39-41; 14:7-9; 15:13; 17:15; 22:7; Deut 23:10-11; Isa 1:16). The term itself could, however, simply mean that Judith was physically clean after washing. The word (and cognates) is used sparingly elsewhere in Judith. Judith's bread in Jdt 10:5 is also called clean or pure. ${ }^{16}$ Those who go up to the temple at the end of the book are also purified ( $\dot{\varepsilon} x \alpha \theta \alpha$ i $\sigma \theta \eta$, Jdt 16:18). The people purify after they have annihilated the Assyrians. Deborah Levine Gera notes that this may have been because they had come into contact with corpses or the possessions of the dead. This can be compared with Num 19:11-22; 31:19-24; 1 Sam 16:5; Ezra 6:20-21. ${ }^{17}$ Judith 12:7 also uses $\beta \alpha \pi \tau i \zeta \omega$. Similar uses of $\beta \alpha \pi \tau i \zeta \omega$ can be found in various ancient Jewish Greek texts such as the LXX 4 Kgdms 5:10, 14. Here Naiman is commanded to immerse himself seven times in the Jordan in order to clean himself. ${ }^{18}$ Sirach 34:25 refers to "washing" in this way after touching a corpse. Josephus also uses $\beta \alpha \pi \tau i \zeta \omega$ to refer to the drowning of Aristobulus in a pool ordered by Herod (War 1.437). $\beta \alpha \pi \tau i \zeta \omega$ most notably became the common term for bathing in the early Christian initiation ritual. Judith, then, bathes in the spring by fully immersing her body (confirmed by the verb $\alpha \dot{\varepsilon} \hat{\beta} \eta$, "coming up," in the next verse). Elsewhere in the book, Judith bathes after her

\footnotetext{
15 Van Den Eynde, "Crying," 224. Levine Gera notes that Judith's claim that she "serves the God of heaven night and day" (Jdt 11:17) indicates that she is planning her escape. See also Levine Gera, Judith, 363 .

16 Levine Gera, Judith, 333, notes that this indicates the bread was kosher.

17 See Levine Gera, Judith, 469.

18 These are discussed at length by Egger-Wenzel, "Judith," 113-114. I am grateful to Professor Egger-Wenzel for sending me a proof-version of this chapter.
} 
lengthy prayer as part of a beauty regime (Jdt 10:3) ${ }^{19}$ The text here uses an unusual verb, $\pi \varepsilon p \varepsilon \varepsilon x \lambda \dot{\sigma} \sigma \alpha \tau$ ("to bathe, wash thoroughly"), which only appears elsewhere in the Septuagint in Tob 6:2. ${ }^{20}$ Overall, there seems to be good reason to conclude that Judith's washing in Jdt 12:7 was part of her purification.

\subsection{Purification for Its Own Sake}

The Book of Judith clearly shows that Judith is a pious woman (cf. Jdt 8:8). It is often noted that her adherence to the law is in part exemplified by bathing in running water. ${ }^{21}$ Judith's prayer and bathing form part of her exemplary image of proper Jewish practice, alongside her fasting and observation of food laws. ${ }^{22}$ Her prayer is one of the principal manifest forms of her piety, most notably in Jdt 9:1-14, but also in Jdt 11:17; 13:4-5, 8, 11, 14. Aside from these instances, Judith also sings to God in Jdt 16:1-17. ${ }^{23}$ Judith's washing, then, could simply be a sign that she observes Jewish purity ritual; her prayer is incidental to her washing. Washing for the purpose of ritual purity can be found in texts like Lev 11-15 and several scholars have suggested that Judith's washing achieved purification for its own sake.

Thomas Hieke notes that "a permanently recurring feature occurs in these chapters: an act that is necessary to regain the status of purity after the reason (or the source) for the impurity is gone: to wash one's body with water." Hieke further connects this with the appearance of so-called miqva'ot in the 2nd century все. Hieke describes Judith as observing "cultic purity" which allows her to pray, noting that Judith remains pure for the whole day (Jdt 12:9). ${ }^{24}$ Judith is cultically pure when she kills Holofernes, but becomes impure once she has struck the killing blow (cf. Num 19:11). Hieke suggests that the purification in Jerusalem and the burnt offering are referring to the ritual in Num 31:19. ${ }^{25}$ According to Hieke, Judith's washing is not necessary for her prayer but does allow her to pray in purity. However, it should be noted that most forms of ritual purification take place over a period of time. Washing often occurs on the

19 Levine Gera, Judith, 331, connects this with Bathsheba (2 Sam 11:2) and Bilhah (Jub. 33:2; T. Reu. 3:11).

20 This verb and its translations are discussed by Egger-Wenzel, "Judith," 107-108. It should be noted here that Egger-Wenzel interprets this bath as a ritual act, although it is unclear exactly why Judith ritually bathes here.

21 See Nickelsburg, "Stories," 49.

22 See Levine Gera, Judith, 11.

23 See further Levine Gera, Judith, 296.

24 See Hieke, "Torah," 103.

25 See Hieke, “Torah," 104. 
final day of a purification period and purification takes full effect after sunset. ${ }^{26}$ Furthermore, it is unclear why Judith would bathe on three successive days. Nothing in the text suggests that she encountered a source of impurity, having confined herself to a tent and eaten alone.

Renate Egger-Wenzel suggests that Judith is a portrayal of Pharisaic practice, which includes maintaining purity for meals, tithing and offering, and observing Sabbaths and festivals. This would mean that Judith's bathing is part of a daily practice of maintaining ritual purity. ${ }^{27}$ This may be the case, but Egger-Wenzel closes the temporal gap between the composition of Judith and rabbinic sources. While there is evidence in Judith to suggest that Judith was concerned with the above matters, I do not see evidence for a practice of daily ritual bathing, and the text used to bolster this claim comes from the Babylonian Talmud (b. Ber 25b:2) which is not the most reliable witness for practices of the 2nd or 1st centuries BCE. ${ }^{28}$

Lawrence Wills argues that Judith's washing connects her action with priestly practice. ${ }^{29}$ Judith takes precautions in order to maintain her pure status, which is threatened by proximity to Holofernes' bedroom and the gentile camp [on gentile impurity, see below]. Judith's priestly portrayal may also create a parallel between a temple sacrifice and the beheading of Holofernes. Holofernes' death could "parody" a ritual sacrifice, which requires that the sacrificial officiant be pure, and thus, Judith must explicitly be shown to have become pure. Wills is careful to note that these motifs do not necessarily have to correspond to a particular purificatory practice, but instead demonstrate a general concern for purity in the Book of Judith. ${ }^{30}$

Aside from purification for its own sake, the explanations of Judith's purpose for purification can be divided into purification due to the contraction of impurity, and purification as preparation. This is not so much a systemic distinction but rather a division based on the emphasis in any purification procedure. Following Catherine Bell's discussion of ritual, purification from impurity can be conceived of as a "rite of affliction," insofar as it seeks to

26 Whether purification is effective before or after sunset was a contentious issue in antiquity. Put briefly, the concept derives from inconsistent laws in Leviticus, only some of which explicitly include waiting until sunset on the last day as part of the purification process. There is a large amount of scholarly treatment of this subject, see Adler, "Second Temple," 69-70; Birenboim, "Tevul Yom"; Harrington, Purity Texts, 79-81; Himmelfarb, "Polemic," 175-188; Kazen, Issues, 117; Klawans, Impurity, 108; Regev, "Individualism," 188189; Werrett, Ritual Purity, 44, 194-196.

27 See Egger-Wenzel, "Judith," 121-122.

28 See Egger-Wenzel, "Judith," 120.

29 See Wills, Judith, 327-332.

$30 \quad$ See Wills, Judith, $33^{-}-332$. 
correct a state of being which is determined to be undesirable. ${ }^{31}$ Purification as preparation may be understood as a rite of "passage," "exchange and communion" or even a "political rite." Bell notes that her distinctions reflect prominent types of ritual-like activity, and that "rituals are multiple and redundant. They do not have just one message or purpose. They have many, and frequently some of these messages and purposes can modify or even contradict one another." 32

\subsection{Purification from Gentile Contact}

Eyal Regev argues that Judith bathed to purify herself from gentile contact. ${ }^{33}$ Regev notes that Judith remains pure until her food is brought to her, but does not expressly say that Judith was purifying in order to eat. ${ }^{34}$ The requirement to avoid gentile defilement is found in some texts, although usually the injunction is against sharing food, rather than washing after contact with gentiles (e.g. 4Q266 5 ii 5-7; $11 \mathrm{Q}_{19}$ 63:10-15). ${ }^{35}$ Josephus notes in War 2.150 that the Essenes wash after contact with foreigners. ${ }^{36}$ Overall, this explanation lacks much internal or external textual support. The gentiles were associated with impurity in some texts, but no text explicitly concerns washing after contact with gentiles as a general Jewish practice. Rather, most of this ideology is usually concerned with marriages and idolatry. Furthermore, the text of Jdt 12:5-9 makes it clear that during her three-day preparation period Judith does not share food with the Assyrians or have much contact with them, yet she still washes. Furthermore, the fact that Judith washes over three days appears redundant. This would indicate that Judith needed to wash every day in order to eat in a pure state, and simply being in the vicinity of the Assyrians conveyed impurity. This notion is not supported by similar texts.

\footnotetext{
31 Bell, Ritual, 115-120.

32 Bell, Ritual, 136. On rites of passage, see 94-102; on rites of exchange and communion, see 108-114; on political rites, see 128-135.

33 Regev, "Non-Priestly Purity," 240. Regev draws similar conclusions elsewhere, comparing Judith with passages in Jubilees, the Damascus Document and rabbinic sources.

34 See Regev, "Individualism," 178.

35 Gentile impurity is discussed by Harrington, Purity Texts, 112-125.

36 Josephus may be implying here that Jews more generally washed after encountering foreigners, as he specifically notes that the Essenes wash after meeting more junior members, "as if they had come into contact with foreigners." Josephus does not mention a similar practice elsewhere.
} 


\subsection{Purification from Menstruation}

A common source of impurity for women in biblical conceptions is menstruation. ${ }^{37}$ The notion that Judith was purifying from this specific impurity comes from a Judeo-Arabic North-African version of the story. Johan Weststeijn demonstrates the connection between this retelling and a legend about Zenobia. ${ }^{38}$ Each narrative contains similar motifs, but the important one for our purposes is that neither Judith nor Zenobia are "ready to have sex with her suitor because she is ritually unclean." ${ }^{39}$ Carey Moore suggests that menstruation could have been the given reason for Judith's delay in seeing Holofernes. ${ }^{40}$ However, as Levine Gera points out, if Judith was purifying because she was menstruating, she would not have had to do so on three successive nights. ${ }^{41}$ Aside from the notion that Judith could have been menstruating, and that this would conveniently explain both her purification and her refusal to go to Holofernes on the first three nights, this explanation offers little that specifically draws from the narrative of the Book of Judith.

\subsection{Purification for Prayer}

Perhaps the most common proposal from scholars is that Judith washes to purify herself before prayer. However, much of the supporting evidence for this explanation comes from non-biblical texts which do not fit well with the narrative of Judith. ${ }^{42}$ In her initial comments on the pericope, Toni Craven only notes that Judith spends three nights having a late bath, prayer and meal. ${ }^{43}$ Craven subsequently argues against Hugo Mantel's conclusions that "Judith's nightly ablution in the Assyrian camp before her prayers proves that the book represents a Sadducean orientation because this sect alone linked washing and prayer. Their strictness in washing the whole body for the purpose of prayer is based on the connection between the work of the heart and the work of the temple." ${ }^{44}$ Craven disagrees that this is solely a Sadducean practice, stating that such practices were widespread in ancient Judaism, but does not offer any

37 There is perhaps a parallel here with Bathsheba who was purifying after her menstruation. Klein, Deborah, 57-61. Klein posits that Bathsheba uses her sexuality to become a mother, even if the text assuages her of any guilt.

38 See Weststeijn, "Zenobia," 306-307.

39 Weststeijn, "Zenobia," 308.

$40 \quad$ Noted by Pervo, "Aseneth," 158 n. 66. Cf. Achilles Tatius, Leucippe and Clitophon 4.7.6.

41 See Levine Gera, Judith, 373.

42 See Moore, Judith, 219 as cited by Lawrence, Washing, 6o n. 40. See also Sanders, Jewish Law, 26o; Wright, "Jewish Ritual Baths," 208.

43 See Craven, Artistry, 98.

44 Craven, Artistry, 119. 
further thoughts on Judith's washing. Craven seems to accept the proposal that Judith washes because she is going to pray. Deborah Levine Gera discusses the possibilities that Judith either bathes because she is going to pray, or because she has been in contact with gentiles. ${ }^{45}$ Levine Gera decides that purifying before prayer is more likely, further suggesting that the purification is perhaps due to the combination of the activities of washing and prayer. ${ }^{46}$ Judith's bath before prayer recalls other late Second Temple period texts which also connect prayer and ritual washing. ${ }^{47}$ One such text is the Letter of Aristeas. Here, the translators of the Septuagint washed their hands in the sea before they prayed. The author writes that this was a "custom of all the Jews," for the purpose of showing they have done no evil (Let. Aris. 305-307). The Sibylline Oracles also attest to the practice of washing before prayer (Sib. Or. $3.591-593 ; 4.162-168) .{ }^{48}$ It seems that Judith's washing could be connected to ensuring she was ritually pure before praying because of the possibility of impurity, or because prayer itself required washing. However, in the most explicit passage concerning prayer in Judith, we are not told that Judith washes (Jdt 9:2-14). ${ }^{49}$ Furthermore, Lawrence notes that washing before prayer is not a feature found in the Hebrew Bible, aside from the possibility that this is indicated in Ps $26: 6-7 .^{50}$ It is important to note that the comparative passages drawn on by scholars to argue in favour of this interpretation do not fit well with Judith's full body immersion. These texts, which refer to a washing ritual for the purpose of prayer, typically speak of handwashing, or mention full body immersion as a sign of repentance for a misdeed rather than so one could pray. While prayer and ritual washing are linked in the Book of Judith because they both attest to Judith's piety, it does not appear that Judith's bath was a requirement for her prayer.

45 On this latter point citing Alon, Jews, 152-157, 201-203 as cited by Levine Gera, Judith, 372.

46 See Levine Gera, Judith, $372-374$.

47 See also Carey Moore who notes that R. Beckwith "sees in Judith's immersing herself rather than just washing her hands before prayer (cf. Jdt 12:5-9) evidence of the book' being written or redacted in the 2nd century BCE." See Moore, "Book of Judith," 64.

48 Noted by Jensen, "Purity," 28. Neither of the Sibylline passages is clearly about prayer but washing before more general addresses to the divine. Josephus' War also describes an Essenic practice of prayer before dawn but does not suggest that they washed their hands before prayer. He does go on to discuss washing before meals in the same section (War 2.128-129). It is also noteworthy that some manuscripts of the Sibylline Oracles state that it is hands that are washed (Sib. Or. 3.592). See Collins, "Sibylline Oracles," 375.

49 For an examination of Judith's prayer in this passage see Day, "Faith," 80-83; Xeravits, "Supplication."

$5^{\circ}$ Lawrence, Washing, 6o. 


\subsection{Purification before Eating}

Another possibility is that Judith bathes in order to eat her evening meal, taken after fasting. ${ }^{51}$ Other Second Temple period texts also have a similar motif, such as 1 QS 5:13 b (cf. 4Q513 1-2 ii 1; 4Q514 1 i 4-10), which refers to the exclusion of members of the Qumran Community from pure food (Judith's bread is also called pure, Jdt 10:5). In Tob 7:9 Tobias and his hosts wash before they eat, and in War 2.128-131 the Essenes pray before dawn, bathe, then one leads a prayer before they eat a communal meal. Wills compares Judith's practice to the impure priest who must bathe before a meal in Lev 22:6, yet this still does not explain why Judith was thought to be impure in the first place. ${ }^{52}$ There is no direct indication in the text of Judith that her purification was for the purpose of her meal. ${ }^{3}$

\section{$4 \quad$ Purification for Military Action}

The narrative of Judith makes it quite clear that Judith purifies during her time in the Assyrian camp. This would only make sense if there were an obvious impurity Judith was removing. No such impurity seems to be apparent, for which Judith would have to had bathed each day, over three days. Therefore, I suggest that the text incorporates a notion that warfare, battle, and violence required certain preparations for the participant(s) not to threaten the holy presence of God or angelic beings. Judith's purification, at this point in the narrative makes sense if the purification is for her upcoming task, her assassination of Holofernes. This can be understood as a circumstantial, prebattle ritual.

Rather than washing for prayer or eating, a number of elements in the narrative suggest that Judith may have purified herself as preparation for her assassination of Holofernes. ${ }^{54} \mathrm{I}$ describe this as purification for military action as it closely follows similar warfare purification procedures in other ancient

$5^{1} \quad$ Noted as a possibility in Lawrence, Washing, 6 o.

$5^{2}$ See Wills, Judith, 328 .

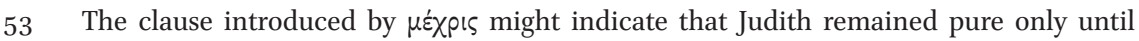
she ate, which could suggest her purity was so she could eat, or that eating rendered her impure. Alternatively, Judith may have simply remained in her tent until she ate.

54 Amy-jill Levine hints at this possibility but does not fully explore it. She notes that in Jdt 16:19, the offering of Holofernes' tent canopy "reappropriates the sacrifice in 13:6-9. The initial ritualized killing, which included the purification and festive garbing of the celebrant ... become part of the communal celebration." Holofernes' assassination requires a kind of priestly purity as it portrayed as part of a sacrifice in ch. 16. See Levine, "Sacrifice," 221. 
texts. Judith's role as a military leader is without question, though despite all her planning and her intrigue in the Assyrian camp, she does not actually go down to battle. Part of this may be to do with the authors' attempts to create a "realistic" 55 image of Judith, a heroine who could have taken the actions she is credited with. Nevertheless, Judith takes action which accomplishes military goals and can be thought of as her participation in "battle" against the Assyrians. Warfare rituals in the Ancient Near East took many forms, which can be sub-divided into pre- and post-battle. Common pre-battle rituals include consulting oracles. Rüdiger Schmitt notes that these rituals should not be conceived of as coercing the deity to intervene, but that "the deity intervenes in reaction to these faithful acts." ${ }^{56}$ These oracles were not just about seeking divine knowledge, but also observing proper procedures prior to conflict. Saul Olyan further distinguishes warfare rituals between "noncircumstantial" and "circumstantial" rites, where the meaning of these latter rites depends on their context. ${ }^{57}$ Thus, I would propose that Judith's washing should be understood as a pre-battle, circumstantial rite, insofar as the meaning is unintelligible without the context of the narrative. In this case, the narrative clearly builds towards Judith's mission to kill Holofernes (Jdt 13:1-10), pausing briefly before this climax to detail her activities immediately before this act. The scene is the crux of the book, and Judith's actions prior to this all prepare her for the assassination.

There are a few ancient parallels to this type of purification before military engagement. This practice is clearly seen in the Sumerian narrative Lugalbanda in the Mountain Cave, where the king Enmerkar and his army bathe "prior to going into battle." ${ }^{58}$ Within the biblical corpus, Deut 23:9-14 maintains that purity is essential in the war camp, and impurity must be removed. Deuteronomy argues that the divine presence ensures victory and requires holiness within the camp to ensure that the Lord remains present. Soldiers must remain clean while in the camp and anything defiling must be removed. This entails proper preparation and purity observance while on campaign. ${ }^{59}$

55 Ackerman, Warrior, 63-69.

56 See Schmitt, "War Rituals," 152-153. These are often followed by execration rituals which involve destruction of pottery. An interesting parallel here is the fact that Judith's claimed purpose to leave the camp is oracular in nature (Jdt 11:17-18). Here Judith tells Holofernes that she will be able to tell them when the Israelites have sinned and the time that they will be given over to the Assyrians.

57 For a full discussion with many biblical examples, see Olyan, "Theorizing," $15-24$.

58 Pryke, Ishtar, 49-52.

59 This is the reason behind Uriah's concern to refrain from returning to Bathsheba while relived from the battlefield (2 Sam 11:11), see Tsumura, Second Book of Samuel, 180. A further example can be found in Num 31:19-20 where Moses commands that after battle, any who have killed or come into contact with a corpse should purify themselves and remain 
A similar notion is also found in the War Scroll, wherein 1QM 7:3-8 details requirements for the eschatological war camp. The participants (all male) are required to maintain purity so that the angels will stay with them in the camp. ${ }^{60}$ Ian Werrett and Stephen Parker describe the War Scroll's purity requirements as "demanding a level of purity that was equal to that of the priesthood in the Hebrew Bible." ${ }^{1}$ Therefore in some conceptions of purity, those on campaign, or at least the eschatological war, are expected to maintain their condition of purity before they reach the battlefield. The ideology of the War Scroll is similar to that of the Rule of the Congregation (1QSa). 1QSa 1:25-27 requires three days of sanctification prior to meetings for various purposes, one of these being a war council. ${ }^{62}$ The text's logic holds that there should be a similar standard of purity as is normally required of priests. Those with various infirmities are excluded (1QSa 2:3-8) because of the presence of angels (1QSa $2: 8-9) \cdot{ }^{63}$ This process of three days of sanctification is the same time frame over which Judith prepares, and her washing could be understood as a sanctification process. In this reading, her violent accomplishment required her to be pure, and she needed to be holy so the divine presence could assure victory (cf. Jdt 13:14; $16: 2,5)$. Her maintenance of purity parallels the maintenance of purity in the war camp generally in both Deuteronomy and the War Scroll. Judith's attribution of her own accomplishment to God is indicative of the same type of thought where divine presence (Deut 23:14) or angels (1QM 7:6) are in the camp and assure victory. ${ }^{64}$

outside the camp for seven days. On this passage, see Kelle, "Postwar Rituals," 211-214. Kelle characterises the washing aspect of this part of postwar rituals as associated with fears about corpse impurity. This may reflect the idea that warfare and purity are conceptually linked but is not explicitly about purity in warfare. A similar notion can be found in Second Maccabees. Again, after battle, Judah and his followers purify before the Sabbath in the midst of a campaign (2 Macc 12:38).

6o The requirement that men who have had a seminal emission remain in the camp likely reflects an idea that they would have had to await until the evening before they became pure, cf. Deut 23:11. Women were perhaps excluded here because they would be unable to participate in campaigns without becoming sources of impurity when they were menstruating, thereby threatening the presence of angels and the potential success of the war. See Werrett and Parker, "Purity," 302-303.

61 Werrett and Parker, "Purity," 301.

62 This text invokes Exod 19:9-11, 14-15. Here the command is that the Israelites launder on the first and second day. The verb here קדשום is for sanctifying, although I'm unclear on how this differs from purification, see 11 Q19 33:7; 35:8; 46:11; 51:8; 11Q20 12:22; 15:2. It is paired with הטהרו ("to purify") in 4Q393 frag. 35 and 4Q400 frag. 1 i 15.

63 See Lawrence, Washing, 130.

64 The divine presence is notably absent in Judith, although there could be the implicit understanding that the Lord is with Judith while she prepares in the Assyrian camp. Geoffrey Miller argues that Judith personifies the divine, "who speaks, acts, and is praised like Yahweh." Miller does not comment on Judith's bath in ch. 12. See further in Miller, 
In this article I have discussed a range of scholarly explanations of Judith's bathing in Jdt 12:7, including purification from or for gentile impurity, menstruation, prayer, or eating. Each of these reasons has some merit, but ultimately, they all fall short of offering a satisfactory explanation of the pericope. This article has suggested therefore, that we consider the possibility that Judith purified herself in preparation for battle. This explanation fits with the narrative in the Book of Judith and can be supported by other evidence of purity concerns in the context of warfare.

\section{Acknowledgement}

The author acknowledges the support of the Arts and Humanities Research Council (UK) as the financial supporter of this paper, specifically in the form of a Doctoral Training Partnership Scholarship through the Midlands4Cities consortium.

\section{Bibliography}

Ackerman, Susan. Warrior, Dancer, Seductress, Queen: Women in Judges and Biblical Israel. ABRL. New York: Doubleday, 1998.

Adler, Yonatan. "Second Temple Period Ritual Baths Adjacent to Agricultural Installations: The Archaeological Evidence in Light of the Halakhic Sources." JJs 59 (2008): 62-72.

Alon, Gedalyahu.Jews, Judaism, and the Classical World. Translated by Israel Abrahams. Jerusalem: Magnes Press, 1977.

Bell, Catherine. Ritual: Perspectives and Dimensions. Oxford: Oxford University Press, 2009 .

Birenboim, Hannan. "Tevul Yom and the Red Heifer: Pharisaic and Sadducean Halakah." DSD 16 (2009): 254-273.

Collins, John J. "Sibylline Oracles." Pages 317-472 in Old Testament Pseudepigrapha. Vol. 1. Edited by James H. Charlesworth. New York: Doubleday, 1983.

"Femme Fatale," 223-245, particularly the summative comments on $243-245$. This complicates how Judith's purification works, but the larger parallel between her behaviour and other warfare-purity texts stands. 
Craven, Toni. Artistry and Faith in the Book of Judith. sBLDs 70. Chico: Scholars Press, 1983.

Day, Linda. "Faith, Character and Perspective in Judith." Jsot 95 (2001): 71-93.

Dombkowski Hopkins, Denise. "Judith." Pages 383-39o in The Women's Bible Commentary. Edited by Carol A. Newsom, Sharon H. Ringe, and Jacqueline E. Lapsley. 3rd ed. Louisville: Westminster John Knox, 2012.

Egger-Wenzel, Renate. "Did Judith Go to the Miqweh?" Pages 101-124 in On Wings of Prayer: Sources of Jewish Worship; Essays in Honor of Professor Stefan C. Reif on the Occasion of His Seventy-fifth Birthday. Edited by Nuria Calduch-Benages, Michael W. Duggan, and Dalia Marx. DCLS 44. Berlin: de Gruyter, 2019.

Esler, Philip F. Sex, Wives, and Warriors: Reading Old Testament Narrative with Its Ancient Audience. Cambridge: James Clark, 2012.

Glancey, Jennifer A. "The Accused: Susanna and Her Readers." Pages 288-302 in A Feminist Companion to Esther, Judith and Susanna. Edited by Athalya Brenner. FC в 7. Sheffield: Sheffield Academic, 1995.

Glancy, Jennifer A. "Susanna 1." Pages 157-158 in Women in Scripture: A Dictionary of Named and Unnamed Women in the Hebrew Bible, the Apocrypha/Deuterocanonical Books, and the New Testament. Edited by Carol Meyers, Toni Craven, and Ross S. Kraemer. Grand Rapids: Eerdmans, 2000.

Hanhart, Robert. Iudith. Septuaginta 8.4. Göttingen: Vandenhoeck \& Ruprecht, 1979.

Harrington, Hannah K. The Purity Texts. London: T\&T Clark, 2004.

Hieke, Thomas. "Torah in Judith: Dietary Laws, Purity and Other Torah Issues in the Book of Judith." Pages 97-110 in A Pious Seductress: Studies in the Book of Judith. Edited by Géza G. Xeravits. DCLS 14. Berlin: de Gruyter, 2012.

Himmelfarb, Martha. "The Polemic against the Țevul Yom: A Reexamination." Pages 175-188 in Between Temple and Torah: Essays on Priests, Scribes, and Visionaries in the Second Temple Period and Beyond. TSAJ 151. Tübingen: Mohr Siebeck, 2013.

Jensen, Morten Hørning. "Purity and Politics in Herod Antipas's Galilee: The Case for Religious Motivation." Journal for the Study of the Historical Jesus 11 (2013): 3-34.

Kazen, Thomas. Issues of Impurity in Early Judaism. ConBNT 45. Winona Lake: Eisenbrauns, 2010.

Kelle, Brad E. "Postwar Rituals of Return and Reintegration." Pages 205-241 in Warfare, Ritual, and Symbol in Biblical and Modern Contexts. Edited by Brad E. Kelle, Frank Ritchel Ames, and Jacob L. Wright. AIL 18. Atlanta: S BL Press, 2014.

Klawans, Jonathan. Impurity and Sin in Ancient Judaism. Oxford: Oxford University Press, 2000.

Klein, Lillian R. From Deborah to Esther: Sexual Politics in the Hebrew Bible. Minneapolis: Fortress, 2003.

Lawrence, Jonathan D. Washing in Water: Trajectories of Ritual Bathing in the Hebrew Bible and Second Temple Literature. AcBib 23. Atlanta: SBL Press, 2006. 
Levine, Amy-Jill. "Sacrifice and Salvation: Otherness and Domestication in the Book of Judith." Pages 208-223 in A Feminist Companion to Esther, Judith and Susanna. Edited by Athalya Brenner. Fс в 7. Sheffield: Sheffield Academic, 1995.

Levine Gera, Deborah. Judith. CEJL. Berlin: de Gruyter, 2014.

Mason, Steve. Flavius Josephus: Translation and Commentary, Volume 9: Life of Josephus. Leiden: Brill, 2001.

Mason, Steve. "Essenes and Lurking Spartans in Josephus' Judean War: From Story to History." Pages 219-261 in Making History:Josephus and Historical Method. Edited by Zuleika Rodgers. JSJSup 110. Leiden: Brill, 2007.

Miller, Geoffrey D. “A Femme Fatale of Whom 'No One Spoke Ill': Judith's Moral Muddle and Her Personification of Yahweh." J SOT 39 (2014): 223-245.

Moore, Carey A. Judith. Ав 40. Garden City: Doubleday, 1985.

Moore, Carey A. "Why Wasn't the Book of Judith Included in the Hebrew Bible?" Pages 61-71 in "No One Spoke Ill of Her": Essays on Judith. Edited by James C. VanderKam. EJL 2. Atlanta: Scholars Press, 1992.

Nickelsburg, George W. E. "Stories of Biblical and Early Post-Biblical Times." Pages 33-87 in Jewish Writings of the Second Temple Period: Apocrypha, Pseudepigrapha, Qumran Sectarian Writings, Philo, Josephus. Edited by Michael E. Stone. Leiden: Brill, 1984.

Olyan, Saul M. "Theorizing Circumstantially Dependent Rites in and out of War Contexts." Pages 15-24 in Warfare, Ritual, and Symbol in Biblical and Modern Contexts. Edited by Brad E. Kelle, Frank Ritchel Ames, and Jacob L. Wright. AIL 18. Atlanta: SB L Press, 2014.

Pervo, Richard I. "Aseneth and Her Sisters: Women in Jewish Narrative and in the Greek Novels." Pages 145-160 in "Women Like This": New Perspectives on Jewish Women in the Greco-Roman World. Edited by Amy-Jill Levine. EJL 1. Atlanta: Scholars Press, 1991.

Pryke, Louise M. Ishtar. London: Routledge, 2017.

Regev, Eyal. "Non-Priestly Purity and Its Religious Aspects according to Historical Sources and Archaeological Findings." Pages 223-244 in Purity and Holiness: The Heritage of Leviticus. Edited by Marcel J. H. M. Poorthuis and Joshua Schwartz. Jewish and Christian Perspectives 2. Leiden: Brill, 2000.

Regev, Eyal. "Pure Individualism: The Idea of Non-Priestly Purity in Ancient Judaism." JSJ 31 (2000): 176-2O2.

Sanders, E. P. Jewish Law from Jesus to the Mishnah: Five Studies. London: SCM, 1990.

Schmitt, Rüdiger. "War Rituals in the Old Testament: Prophets, Kings, and the Ritual Preparation for War." Pages 149-161 in Warfare, Ritual, and Symbol in Biblical and Modern Contexts. Edited by Brad E. Kelle, Frank Ritchel Ames, and Jacob L. Wright. AIL 18. Atlanta: SBL Press, 2014. 
Tsumura, David Toshio. The Second Book of Samuel. NIсот. Grand Rapids: Eerdmans, 2019 .

Van Den Eynde, Sabine. "Crying to God: Prayer and Plot in the Book of Judith." Bib 85 (2004): 217-231.

Werrett, Ian C. Ritual Purity and the Dead Sea Scrolls. ST DJ 72. Leiden: Brill, 2007.

Werrett, Ian C., and Stephen Parker. "Purity in War: What is it Good for?" Pages 295-316 in The War Scroll, Violence and Peace in the Dead Sea Scrolls and Related Literature: Essays in Honour of Martin G. Abegg on the Occasion of His 65th Birthday. Edited by Kipp Davis, Kyung S. Baek, Peter W. Flint, and Dorothy Peters. STDJ 115. Leiden: Brill, 2015 .

Weststeijn, Johan. "Zenobia of Palmyra and the Book of Judith: Common Motifs in Greek, Jewish, and Arabic Historiography." JSP 22 (2013): 295-320.

Wills, Lawrence M.Judith: A Commentary on the Book ofJudith. Edited by Sidnie White Crawford. Hermeneia. Minneapolis: Fortress, 2019.

Wright, Benjamin G., III. "Jewish Ritual Baths-Interpreting the Digs and the Texts: Some Issues in the Social History of Second Temple Judaism." Pages 190-214 in The Archaeology of Israel: Constructing the Past, Interpreting the Present. Edited by Neil Asher Silberman and David B. Small. JSOTSup 237. Sheffield: Sheffield Academic, 1997.

Xeravits, Géza G. "The Supplication of Judith (Judith 9:2-14)." Pages 161-178 in A Pious Seductress: Studies in the Book of Judith. Edited by Géza G. Xeravits. DCLS 14. Berlin: de Gruyter, 2012. 